\title{
Growth and Pigmentation of Micrococcus radiodurans
}

\author{
By D. THIRKELL \\ Department of Biochemistry, Bute Medical Buildings, St Andrews, Fife
}

(Accepted for publication 2I October 1968)

\begin{abstract}
SUMMARY
Micrococcus radiodurans grew well between $25^{\circ}$ and $40^{\circ}$ with an optimum at $25^{\circ}$ to $30^{\circ}$. At $35^{\circ}$ pigmentation lagged behind growth after 3 days, growth and pigmentation showed similar maxima at $25^{\circ}$. The bacterium appeared to synthesize five carotenoids, at least two of which have the same chromophore and are keto-carotenoids.
\end{abstract}

\section{INTRODUCTION}

Micrococcus radiodurans is the radiation-resistant micro-organism isolated from samples of supposedly sterile meat by Anderson, Nordan, Cain, Parrish \& Duggan (1956). Mosely \& Schein (1964) reported good growth and pigmentation on agar containing $0.2 \%(\mathrm{w} / \mathrm{v})$ aspartic acid along with tryptone, glucose and yeast extract at $\mathrm{pH} \mathrm{7 \cdot 2.}$ This is consistent with the observation of Goodwin (1963) that the addition of intermediates of the citric acid cycle enhances pigmentation in many bacteria. The general characters of the organism have been published by Anderson et al. (1956), Thornley (1963), Krabbenhoft, Anderson \& Elliker (1965), and Kaplan \& Zavarine (1965).

The present work reports studies on rates of growth and pigmentation for this bacterium at various temperatures and outlines qualitative data on the nature of the pigments. The latter are compared with the results of Bamji \& Krinsky (1966) who examined the pigments of a radiation-resistant micrococcus.

\section{METHODS}

Micrococcus radiodurans was a gift from Dr B. E. B. Moseley, Molteno Institute, Cambridge. It was grown either in aspartate broth or on aspartic agar plates where the medium had the following composition: tryptone (Oxoid Ltd.) $0.5 \%(\mathrm{w} / \mathrm{v})$; glucose $0.1 \%(\mathrm{w} / \mathrm{v})$; yeast extract (Difco) $0.3 \%(\mathrm{w} / \mathrm{v})$; aspartic acid $0.2 \%(\mathrm{w} / \mathrm{v})$; pH to $7 \cdot 2$ with $\mathrm{NaOH}$. If required, $2 \%(\mathrm{w} / \mathrm{v})$ agar no. 3 (Oxoid Ltd.) was added before autoclaving.

Relationship of growth and temperature. Twelve bottles of aspartic broth were inoculated with $2 \mathrm{ml}$. of a 2-day broth culture and were incubated in pairs at 15,20 , 25, 30, 35 and $40^{\circ}$ in shaking incubators. One ml. samples were withdrawn with a sterile syringe at intervals.

Relationship of pigmentation with time at $35^{\circ}$. Bacteria were grown on aspartic agar plates which were inoculated by flooding with 2-day broth cultures. At daily intervals up to 6 days, the bacteria from an equal number of plates were harvested and suspended 
in $95 \%(\mathrm{v} / \mathrm{v})$ methanol. They were subjected to ultrasound for a total of $5 \mathrm{~min}$. in a Mullard ultrasonicator. The suspension was brought to the boil under a reflux condenser and immediately cooled. After centrifugation, the bacterial sediments were re-extracted until colourless. The carotenoids were purified by the lipid precipitation

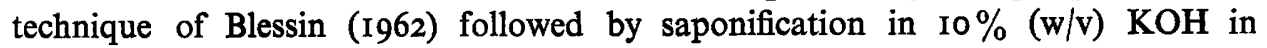
methanol overnight at room temperature in an atmosphere of nitrogen. The unsaponifiable material was recovered in the usual way, to taken dryness, dissolved in methanol and read at $478 \mathrm{~m} \mu$ on a spectrophotometer. The bacterial sediments were taken to dryness and constant weight and the optical density of the pigments expressed per unit weight of bacterial sediments.

Variation of pigmentation with temperature at 3 days. Bacteria were grown as for pigmentation above, but at $15,20,25,30,35$ and $38^{\circ}$ and they were harvested after 3 days. The pigments were extracted and the bacterial sediments treated as described.

Carotenoids. Bacteria were grown at $35^{\circ}$ on aspartate agar and harvested after 3 days. The carotenoids were extracted and purified as described. They were concentrated and separated by preparative thin layer chromatography on $250 \mu$ layers of silica gel G (Merck) using light petroleum (b.p. 60-80 $) /$ acetone $(50 / 50 ; \mathrm{v} / \mathrm{v}$ ) as solvent. The material was strip loaded on the plates using the Desaga applicator (Camlab (Glass) Ltd.) and dried under a stream of nitrogen. The plates were developed in glass tanks gassed out with nitrogen. After development, the plates were viewed with the naked eye, under ultra-violet illumination and after spraying with a saturated solution of antimony trichloride in chloroform (Morton, 1942). The $R_{f}$ values of the resolved fractions were determined and the absorption spectra of the two most abundant fractions, eluted into methanol, were read. The presence of keto groups in these fractions was investigated by two techniques: (i) formation of 2,4,dinitrophenylhydrazones (Fieser, 1955), (ii) reduction with $\mathrm{LiAlH}_{4}$ (Goodwin, 1956).

\section{RESULTS}

Growth and temperature. The organism grew well at temperatures between 25 and $40^{\circ}$ with an optimum between 25 and $30^{\circ}$ (Fig. I). Bacterial numbers declined fairly rapidly after reaching their peak, a result which is different from that found with Sarcina flava (Thirkell, Strang \& Carstairs, 1965).

Pigmentation with time at $35^{\circ}$. Pigmentation reached a maximum of I.6 O.D. units/ mg. organism after 3 days and hence lagged behind growth which at $35^{\circ}$ reached a peak in bacterial numbers at about $48 \mathrm{hr}$ and remained steady for a further $24 \mathrm{hr}$. After 3 days, both growth and pigmentation showed similar maxima at $25^{\circ}$ (Fig. 2). In a duplicate experiment omitting aspartic acid from the medium, only slight pigmentation was observed though good growth was supported.

Nature of the pigments. The total carotenoid extract resolved into five components which differed in colour from pale yellow to bright red-orange. Fraction 5 , the least polar, was pale yellow and was only detected when the plates were very heavily loaded; fraction 4 was present in the greatest concentration. Satisfactory spectra were recorded only for fractions 2 and 4 after elution into methanol, and both of these fractions appear to be keto-carotenoids. The data obtained for the fractions are summarized in Table $\mathrm{I}$. 


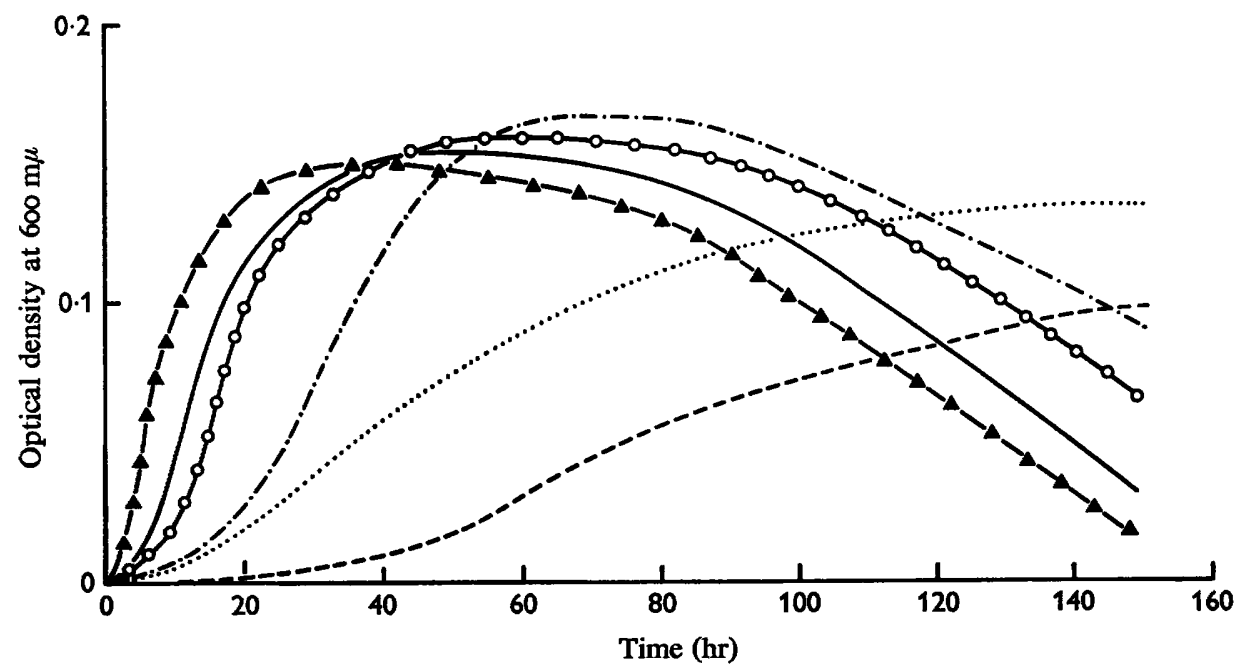

Fig. I. Growth of $M$, radiodurans at different temperatures. Samples were withdrawn at intervals up to $159 \mathrm{hr}$ incubation from shaken cultures. Optical density values were recorded at $600 \mathrm{~m} \mu .---15^{\circ}, \cdots \cdots 20^{\circ} ;-\cdot-\cdot 25^{\circ} ; \mathrm{O}-\mathrm{O}-\mathrm{O} 30^{\circ} ;-35^{\circ} ; \Delta-\Delta-\Delta 40^{\circ}$.

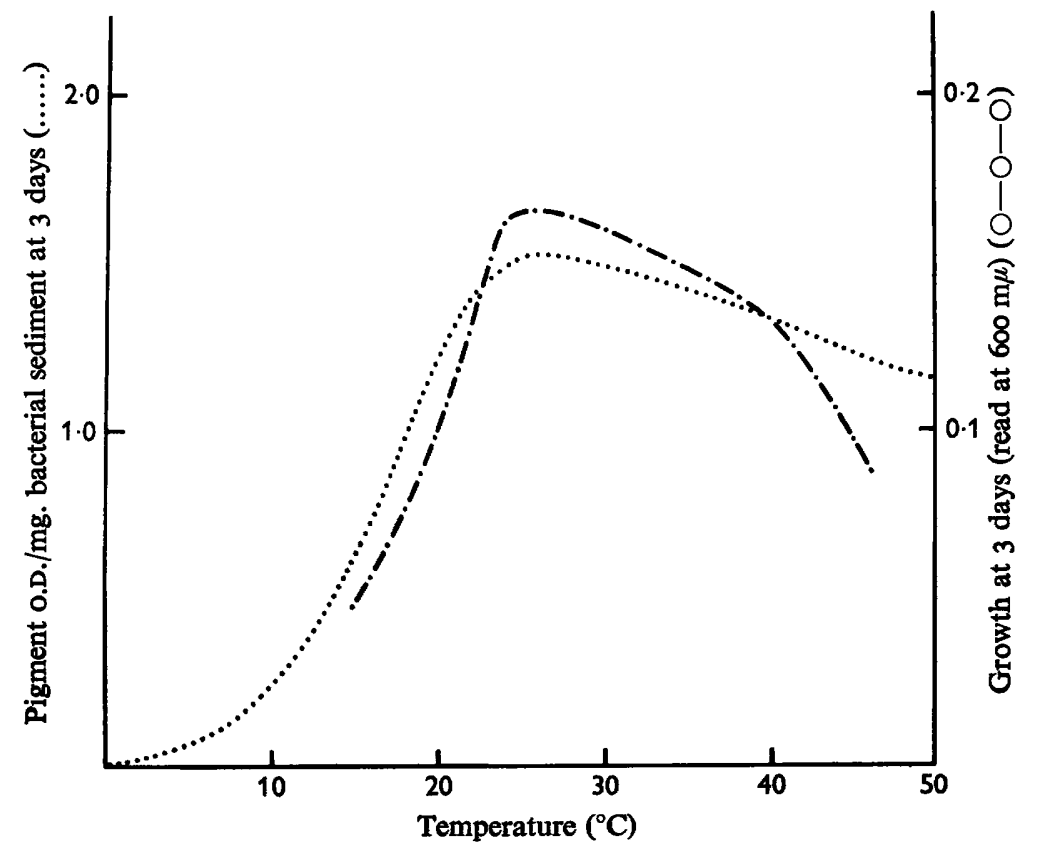

Fig. 2. Growth and pigmentation of $M$. radiodurans at various temperatures after 3 days incubation.

\section{DISCUSSION}

The optimum temperature for the growth of Micrococcus radiodurans agreed with that quoted by Anderson et al. (1956), but good growth was supported over a fairly wide range of temperature. Omission of aspartate from the medium reduced pigmenta- 
tion significantly though good growth was still supported. Other experiments in this laboratory showed that nutrient agar enriched with I \% (w/v) glucose suppressed pigmentation.

Table I. Data for the pigments of Micrococcus radiodurans

$\begin{array}{ccclc}\text { Fraction } & R_{f} & \begin{array}{c}\lambda_{\max } \\ \text { (Methanol) } \mathrm{m} \mu\end{array} & \begin{array}{l}\text { Colour (vis.) } \\ \text { Tests for } \\ \text { keto group(s) }\end{array} \\ 2 & 0.12 & - & \text { Orange } & - \\ 3 & 0.21 & 475 & \text { Orange-red } & + \\ 4 & 0.71 & - & \text { Orange } & - \\ 5 & 0.84 & 475 & \text { Orange-red } & + \\ & 0.88 & - & \text { Pale yellow } & -\end{array}$

All pigments gave a dark blue colour with $\mathrm{SbCl}_{3}$.

All pigments were absorbent under ultraviolet illumination.

The finding that pigmentation and growth showed similar maxima at $25^{\circ}$ after three days is interesting since many bacteria show a lower temperature for optimúm pigmentation than for growth (Goodwin, 1963).

The fifth pigment, as against the four reported by Bamji \& Krinsky (1966), was only observed when certain plates were overloaded. All the fractions reported by Bamji \& Krinsky (1966) were keto-carotenoids, but only fractions 2 and 4 were available in sufficient concentrations to demonstrate this in this work. Again, all four pigments reported previously had the same chromophore, and although satisfactory spectra of fractions I and 3 were not determined, they had a different visible colour which would suggest that they had a lower $\lambda_{\max .}$. The low absorption readings which were obtained, however, suggested that the spectra had no fine structure and therefore fractions $I$ and 3 are probably also keto-carotenoids.

\section{REFERENCES}

Anderson, A. W., Nordan, H. C., Cain, R. F., Parrish, G. \& Duggan, D. (1956). Studies on a radio-resistant micrococcus, I. Isolation, morphology, cultural characteristics and resistance to $\gamma$-radiation. Food Technol. 1o, 575.

BAMI, M. S. \& KRINSKY, N. I. (I966). The carotenoid pigments of a radiation-resistant micrococcus species. Biochim. biophys. Acta $115,276$.

Blessin, C. W. (1962). Carotenoids of corn and sorghum. Cereal Chem. 39, 236.

FIESER, L. F. (1955). Experiments in Organic Chemistry. Boston: Heath and Co.

GoodwIN, T. W. (1956). Studies in carotenogenesis. Biochem. J. 63, 481.

GoodwIN, T. W. (1963). Biosynthesis of Vitamins and Related Substances. London: Academic Press.

KAPLAN, H. S. \& ZAVARINE, R. (1965). Correlation of bacterial radiosensitivity and DNA base composition. Biochem. biophys. Res. Comm. 8, 432.

Krabbenhoft, K. L., ANDERSON, A. W. \& Elliker, P. R. (1965). Ecology of M. radiodurans. Appl. Microbiol. 13, 1030.

Morton, R. A. (1942). Absorption Spectra Applied to Vitamins and Hormones. London: A. Hilgar.

MoseleY, B. E. B. \& SCHEN, A. H. (1964). Radiation resistance and DNA base composition of $M$. radiodurans. Nature, Lond. 203, 1298.

Thirkele, D., Strang, R. H. C. \& Carstairs, E. A. (1965). Experiments with Sarcina flava. I. Relationship of time and temperature with growth and pigmentation. Phytochemistry 4, 155.

THORNLEY, M. J. (1963). Radiation resistance among bacteria. J. appl. Bact. 26, 334 . 